\title{
Characterization and Diversity of plant growth promoting Endophytic and Rhizosphere Bacteria isolated from theRhizosphere and tissues of Pepper and their effect on plant growth promotion and disease suppression of Phytophthora capsici
}

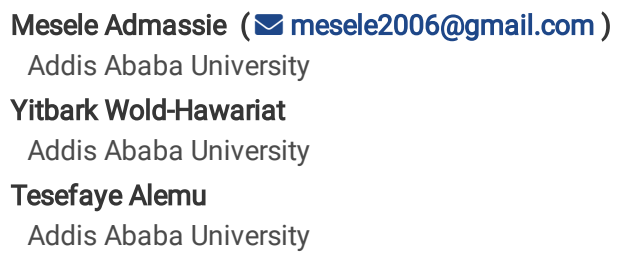

Research Article

Keywords: plant growth promoting bacteria, Phytophthora, antagonism, phytopathogens, bio fungicide, endophyte

Posted Date: April 20th, 2021

DOl: https://doi.org/10.21203/rs.3.rs-422729/v1

License: (c) (i) This work is licensed under a Creative Commons Attribution 4.0 International License. Read Full License 


\section{Abstract}

Plant growth promoting rhizo and endophytic bacteria were isolated from different parts of pepper from south eastern Ethiopia. Plant growth promoting bacteria (PGP) are those that may be used to promote plant growth and suppress plant diseases. The objectives of this study were to identify and characterize PGPB indigenous to pepper rhizosphere and endophyte bacteria in Ethiopia, and to determine their capacity to suppress Phytophthora capsici in pepper. From a total of 60 isolates, 20 were selected based on their in vitro antagonism activity of phytopathogens and plant growth promoting traits. From the total 60 strains representing, 38 rhizosphere, and 22 endophytic bacteria were identified based on biochemical assays of semi-automated Vitec 2 compact and ten potential bacteria further identified by molecular methods. Results revealed that only one isolate of rhizosphere and three endophytic bacteria showed more than $50 \%$ suppression of test pathogens. The isolates were evaluated for their ability to solubilize phosphate, as well as for ammonia, indole acetic acid, hydrogen cyanide, and biofilm production. The selected isolates produced $\left(0.2-93 \mu \mathrm{g} \mathrm{mL}^{-1}\right)$ of indole-3-acetic acid, without supplemented with tryptophan, while supplemented with tryptophan it produces $\left(11.23-159 \mu \mathrm{g} \mathrm{m}^{-1}\right)$. The activities of plant growth-promoting were assessed by measuring their effect on the number of lateral roots, root and shoot length of Arabidopsis plants, and germination percentage of pepper plants. Pepper plants grown from seeds that were treated with these PGPB strains showed significantly higher levels of germination, seedling vigor, and growth, compared to non-treated control plants. Since these PGPB inoculants showed multiple characters useful to the host plants, they may be used as an alternative in the production of new, safe, and effective seed treatments as bio-fungicides. Generally, this work exhibits the potential of bacterial isolates to control Phytophthora infection and promote plant growth.

\section{Introduction}

The increment of crop productivity is essential for feeding the increasing population in developing countries and often depends on the use of synthetic fertilizers. However, contentious use of these synthetics microcidal was shown to decrease bacterial diversity in soil ${ }^{1}$ and can also have harmful impacts on the environment, such as leaching of phosphorus and nitrogen into groundwater, and increasing the pollution of soil and water ${ }^{2}$. To reduce the continuous use of chemicals and to increase the sustainability of agricultural practices is the use of efficient, nutrient mobilizing microorganism's fertilizers ${ }^{3,4}$.

Plant growth promoting bacteria (PGPB) that form a close relationship with their host plants are important to increase plant productivity and health under various environmental conditions ${ }^{5}$. Endophytes and rhizosphere bacteria colonize plant tissues and roots without any apparent pathogenic symptoms and begin beneficial associations with their plant host by synthesis of phytohormone, production of an enzyme, and nutrient mobilization and translocation, such as phosphate (PO4 - 3 ) solubilization, nitrogen fixation, and ammonia (NH3) production ${ }^{6,7}$. The rhizosphere and the internal tissues of most plants are commonly invaded by bacteria and should have various effects on the event and physiology of the host plant. The internal tissue and rhizosphere of plants get benefits from these bacteria.

Endophytic bacteria that reside within the interior of plant tissues provides different benefits to plants, which include the promotion of plant growth and induce defense mechanisms to plants, and producing antibiotics against fungal pathogens ${ }^{8}$. Also, it plays a crucial role in the healthiness and development of plants under different environmental stresses. Endophyte bacteria, which inhabit healthy plant tissues without causing any damage to the host, have enormous potential as biological control agents against plant diseases. ${ }^{9}$. Even though it has different ecological niches, rhizo-bacteria and endophytic bacteria use the same mechanisms to promote plant growth and control phytopathogens ${ }^{10}$. For instance, they promote plant growth by producing indole-3-acetic acid (IAA), synthesis of phosphate solubilizing, and production of ammonia ${ }^{11} .{ }^{12}$ studied bacterial inoculants as bio fertilizers and found that improved growth and increased yield of cereal crops ${ }^{13}$ has been reviewed the importance of endophytic, and rhizosphere microorganisms within the plant growth, particularly in unfavorable soil conditions. The impact of some plant-associated microorganisms is connected to their unique metabolic activities, like nitrogen (N2) fixation, phosphate solubilization, the ad, production of IAA, ${ }^{14}$. To grasp the interaction between host plants and their rhizosphere and endophytic bacteria, it's important to spot the variety of this bacteria related to the plants.

In the present study isolation of plant growth-promoting (PGP) endophytic and rhizosphere bacteria from pepper cultivated region in the Eastern part of Ethiopia and investigating the effects of these bacteria on inoculated pepper seedlings growth enhancement, and genus wise screening of their diversity.

\section{Methods And Materials}

\subsection{Isolation of Rhizosphere bacteria from pepper plants}

The rhizosphere soil samples were collected from all the fields' surveys by uprooting the healthy chili plant carefully without damaging the basis system. It is then, shakes gently to get rid of the surplus soil and brings it to the laboratory by a sterile polythene bag. The procedure was implemented using the following methods ${ }^{15}$.

Ten grams of soil sample was taken separately and suspended in $90 \mathrm{ml}$ of sterile water and stir well to give 1:10 dilution (10 - 1). One $\mathrm{ml}$ from this was transferred to a tube containing nine $\mathrm{ml}$ of sterile water to give 1:100 dilutions $\left(10{ }^{2}\right)$. One $\mathrm{ml}$ from this was transferred to a tube containing nine $\mathrm{ml}$ of sterile water to give 1:1000 (10 - 3). Similarly, $10^{-4}$ and $10-5$ dilution for isolation of bacterial spp. were used. One ml of every dilution was added into Petri plates and $20 \mathrm{ml}$ of separate sterile and cooled macConkey and nutrient agar medium were poured and every treatment was replicated 3 times. The representative bacterial colonies were picked up, purified, and preserved at $-22{ }^{\circ} \mathrm{C}$ for further use.

\subsubsection{Determination of $\mathrm{CFU} / \mathrm{ml}$}

The pour plate methods were used for the determination of $\mathrm{CFU} / \mathrm{ml}$ of the bacterial suspension. 
The number of $\mathrm{CFU} / \mathrm{ml}$ was calculated as under ${ }^{16}$

No. of bacterial colonies

$\mathrm{CFU} / \mathrm{ml}=-------------------$

Dilution ×amount plated

2.2 Isolation of endophytic bacteria from pepper plants

Endophytic bacteria were isolated from the inner tissues of roots, leaves, fruits, and stems of apparently healthy pepper varieties (different cultivars) collected from major Eastern parts of Ethiopia pepper growing regions following the methods of ${ }^{17}$ with some modifications. Samples were surface sterilized with $2 \%$ sodium hypo chloride followed by $70 \%$ ethanol for 3 min and rinsed five times in sterile distilled $\mathrm{H}_{2} \mathrm{O}$. Five grams of surface sterilized plant parts were grinded separately with a waring blender in phosphate buffer saline (PBS) and were centrifuged $(60 \mathrm{~g})$ for five minutes. The supernatant was serially diluted up to $10^{-}$

${ }^{5}$, poured on nutrient agar and macCkonkey agar plates, and incubated at $28{ }^{\circ} \mathrm{C}$ for $48 \mathrm{hrs}$. The bacterial colonies from each tissue were selected and subcultured on nutrient agar and stored for further studies. Surface sterility was checked for every sample to observe the efficiency of the disinfection procedure. For this, $0.1 \mathrm{ml}$ of the last wash was poured to agar media and incubated at $28{ }^{0} \mathrm{C}$ for a sterility check.

\section{Bacterial Identification}

\subsection{Morphological Identification}

\subsubsection{Gram stain}

A loop full culture was taken and smear prepared on a clean glass slide. After the smear dried, it absolutely was stained as per instruction given in Gram's staining reagents kit. Then, the morphological characters were noted.

3.2 Biochemical and physiological characterization

The proficiency of bacteria to utilize different metabolites was done through performing biochemical tests. The bacterial bio agents were preliminarily identified using Gram stain, and biochemical tests (Catalase, Indole production, Oxidase test, urea test, Citrate utilization test, gas glucose production, $\mathrm{H}_{2} \mathrm{~S}$ production test, Urea utilization test, Lysine Decarboxylase test, Fermentation of Sugars (Sugar Utilization Test)). Subsequently, selective media like MacConkey agar was used to isolate gram-negative bacteria, and was also identification was performed with a semi-automatic Vitek 2 compact (bioMérieux) system using GP ID REF21342 (Identification-Gram-positive bacteria) and GN ID REF21341 (Identification-Gram-negative bacteria) cards. All the test procedures were followed in keeping with the manufacturer's instructions.

\subsection{Molecular Identification}

A volume of $1.5 \mathrm{~mL}$ of overnight-grown cultures of each isolate were harvested by centrifugation at $11,000 \mathrm{~g}$ for 5 min and removal of the supernatant by gentle pipetting. Genomic DNA of the bacterial isolates was extracted using the ISOLATE II Plant DNA Kit (Bioline, Inc., Taunton, MA, United States) according to the manufacturer's instructions. The isolated DNA was subjected to PCR amplification with a universal 16S primer set consisting of forward primer $63 f$ (5'CAG GCC TAA CAC ATG CAA GTC-3') and reverse primer 1387r (5'-GGG CGG WGT GTA CAA GGC-3') (Pharmacia) ${ }^{18}$. PCR was performed in a $25.5 \mu L$ reaction mixture containing: $18 \mu \mathrm{L}$ pure water, $5 \mu \mathrm{L}$ of $10 \mathrm{X}$ TBE buffer, $0.5 \mu \mathrm{L}$ of dNTPs $(10 \mu \mathrm{M}), 0.5 \mu \mathrm{L}$ of $10 \mu \mathrm{M} 63 \mathrm{~F}$ primer, $0.5 \mu \mathrm{L}$ of $10 \mu \mathrm{M} 11387 \mathrm{R}$ primer, and $1 \mu$ l of DNA template. The PCR thermocycler conditions were $30 \mathrm{~s}$ at $95 \circ \mathrm{C}$ for initial denaturation, 30 cycles of $30 \mathrm{~s}$ at $95 \circ \mathrm{C}, 30 \mathrm{~s}$ at $55 \circ \mathrm{C}$ for annealing and $1 \mathrm{~min}$ at $72 \circ \mathrm{C}$, followed by $5 \mathrm{~min}$ at $72 \circ \mathrm{C}$ for final extension. Amplifications were performed in duplicate for each sample, and the presence of the predicted PCR products was confirmed by $1 \%$ agarose gel electrophoresis. The PCR products were purified using the Wizard R SV PCR Clean-Up System (Promega), and purity was confirmed using a Nano Drop on spectrophotometer, then cloned, and sends to the Molecular cloning laboratories in San Francisco CA, for sequencing by DNA Analyzer (Applied Biosystems).

\section{Plant Growth Promoting Bacteria}

PGPB are bacteria that can promote plant growth, including those that are free-living, have symbiotic relationships with rhizosphere plants, and bacterial endophytes that can colonize interior tissues of plants. PGPB could promote plant growth directly by either enhancing resource acquisition or managing plant hormone levels, or indirectly by decreasing the deleterious impacts of different pathogenic microbes on plant growth and development ${ }^{19}$.

\subsection{Direct mechanism}

\subsubsection{Production of an Indole Acetic Acid (IAA)}

The production of indole acetic acid was verified with some modifications via the colorimetric method developed by ${ }^{20}$. At $500 \mathrm{rpm}$ for $7 \mathrm{days}$ of $10^{\wedge} 8 \mathrm{cfu} / \mathrm{ml}$ of an overnight bacterial culture grown on tryptophan broth was centrifuge. The supernatant was reserved and $1 \mathrm{ml}$ was mixed with $2 \mathrm{ml}$ of Salkowski's reagent ( $2 \% 0.5 \mathrm{FeCl} 3$ in $35 \%$ perchloric acid (CLO4) solution) and kept within the dark. Then the optical density (OD) was recorded at $530 \mathrm{~nm}$ at different L-tryptophan concentrations.

L-Tryptophan utilized was studied by estimating the residual I-tryptophan remaining in the broth by previously estimated spectrophotometric test ${ }^{21}$. Briefly, 1 $\mathrm{ml}$ of cell-free aliquots was taken from the broth and evaporated on a boiling water bath to dryness, followed by the addition of $1 \mathrm{ml}$ of nitric acid ( $16 \mathrm{~mol} / \mathrm{l}$ ) and incubation at $50{ }^{\circ} \mathrm{C}$ for $15 \mathrm{~min}$. The contents were then cooled at room temperature following the addition of $4 \mathrm{ml}$ of sodium hydroxide (5 mol I/I) 
solution; ethyl alcohol (97\%) was used to make the final volume of $10 \mathrm{ml}$. After mixing the contents, absorbance was recorded at $360 \mathrm{~nm}$. Quantification of Itryptophan was performed using the standard curve.

\subsubsection{Qualitative and Quantitative Measurement of Phosphate Solubilization}

Qualitative tests of bacterial isolates were screened for their TCP solubilizing activity on PKV plates. Isolates had been spot inoculated at the middle of the agar plate aseptically. All of the plates are incubated at $28{ }^{\circ} \mathrm{C}$ for 5 days. A clean region around a growing colony showed solubilization of phosphate and recorded as phosphate solubilization index (PSI). PSI was calculated by dividing the ratio of the full diameter (colony + halo region) by to the colony diameter 22 ,

PSI = Colony diameter + Halo zone diameter

Colony diameter

All the observations have been recorded in triplicate. Strains showing clear zones around their colonies could recognize as phosphate solubilizing bacteria.

The phosphate-solubilizing isolates which showed in the qualitative test were assessed in vitro quantitatively on 15th day post-inoculation (DPI). Bacterial cultures were grown in triplicate in Pikovskaya broth medium $\left(\mathrm{Ca}_{3}\left(\mathrm{PO}_{4}\right)_{2}, 5 \mathrm{~g} ;\left(\mathrm{NH}_{4}\right)_{2} \mathrm{SO}_{4}, 0.5 \mathrm{~g} ;\right.$ glucose, $10 \mathrm{~g} ; \mathrm{NaCl}, 0.2 \mathrm{~g} ; \mathrm{MgSO}{ }_{4} 7 \mathrm{H}_{2} \mathrm{O}, 0.1 \mathrm{~g} ; \mathrm{KCl}, 0.2 \mathrm{~g} ; \mathrm{yeast}$ extract, $0.5 \mathrm{~g} ; \mathrm{MnSO}_{4} \mathrm{H}_{2} \mathrm{O}, 0.002 \mathrm{~g}$ and $\mathrm{FeSO}_{4} 7 \mathrm{H}_{2} \mathrm{O}, 0.002 \mathrm{~g}$. per liter of solution)at room temperature at $150 \mathrm{rpm}$ on a shaker. Cultures were then centrifuged at $4000 \mathrm{rpm}$ for 10 minutes to get cell-free supernatant. The concentration of the soluble phosphate was estimated from the supernatant by stannous chloride method after five, ten, and fifteen days of incubation ${ }^{23}$ using spectrophotometer ( $6405 \mathrm{UV}$-Visible, JENWAY) at $882 \mathrm{~nm}$. To calculate the amount of phosphate, optical density against concentration $\left(\mu \mathrm{g} \mathrm{mL}^{-1}\right)$ the standard solution was plotted. The standard solution was prepared by dissolving $0.2195 \mathrm{~g}$ of $\mathrm{KH}_{2} \mathrm{PO}_{4}$ in $1 \mathrm{~L}$ water to get $50 \mu \mathrm{g} \mathrm{mL}^{-1}$ solutions. Further dilutions $\left(2,4,8,10,20,30,40\right.$, and $\left.50 \mu \mathrm{g} \mathrm{mL}^{-1}\right)$ were made to get the standard curve of $\mathrm{KH}_{2} \mathrm{PO}_{4}$. Uninoculated sterilized Pikovskaya broth medium was used as control. There were three replicates for each treatment and each treatment received an equal amount of culture broth (inoculum adjusted to $\sim$ x $10^{8} \mathrm{CFU} \mathrm{mL}{ }^{-1}$ ). Change in $\mathrm{pH}$ of broth culture in response to phosphorus was recorded for cell-free supernatant measured with a $\mathrm{pH}$ meter at each sampling time. The correlation coefficient $(r)$ between soluble $\mathrm{P}$ and $\mathrm{pH}$ value was calculated using Graph pad prism software (Graph pad prism Inc, California, USA) at $1 \%$ level of significance.

\subsubsection{Detection of biofilm formation}

\subsubsection{Plate Method}

Qualitative assay of biofilm-producing microorganism was detected using the congo red agar method, as a result of the dark color of colonies inoculated on CRA medium ${ }^{24}$. The CRA medium is prepared by mixing $0.8 \mathrm{~g}$ of congo red, and $36 \mathrm{~g}$ of sucrose to $37 \mathrm{~g} / \mathrm{L}$ of Brain heart infusion (BHI) agar. The mucoid nature of the bacterial colonies was studied through the cultivation of all the strains on Congo red agar (CRA) plates ${ }^{25}$. Fresh bacterial cultures were streaked on the CRA plates. Plates were incubated at $28^{\circ} \mathrm{C}$ for $48 \mathrm{~h}$ and seen for the attribute of black colony morphology of the media.

\subsubsection{Tube Method (TM)}

The tube methods of biofilm formation through the bacterial isolates have been located by the way of adherence to the partitions of culture tubes ${ }^{26}$.

The inoculum was prepared using $5 \mathrm{ml}$ of nutrient broth. After $48 \mathrm{~h}$ of incubation at $28^{\circ} \mathrm{C}$, turbidity was adjusted to 0.5 ( $\left.10^{\wedge} 8 \mathrm{CFU} / \mathrm{ml}\right) \mathrm{McFarland}$ standards for the biofilm experiment, $100 \mu \mathrm{l}$ of inoculum was transferred into three $\mathrm{ml}$ of nutrient broth in 10-13 $\mathrm{ml}$ of test tubes.

All the test tubes were incubated at $28{ }^{0} \mathrm{C}$ for 48 h.in nutrient broth. The tubes were washed with three $\mathrm{ml}$ of $2 \mathrm{X}$ phosphate buffer saline (PBS). The isolates of which biofilms formed on the walls of test tube are stained with $3 \mathrm{ml}$ of $2 \%$ crystal violet for $1 \mathrm{hr}$. Then, crystal violet-stained test tubes were rinsed twice with PBS and allowed to dry, and the occurrence of visible film lined the walls, and the bottom of test tubes indicates the presence of biofilm ${ }^{27}$. All the tubes had been added with $33 \%$ of $1.5 \mathrm{ml}$ glacial acetic acid and blended gently. Optical density (OD) was measured in the spectrophotometer at 570 nm. The OD values of the samples were measured with the PBS as control. The biofilm formation experiment in tubes was carried out by using both glass and plastic (PVC) tubes. To interpret results, categorization can be done as no biofilm production (0), weak (+ or 1$)$, moderate ( ++ or 2$)$, and strong biofilm production (+++ or 3 ) by the calculation of cutoff value (ODc) shown below ${ }^{28}$ : $O D \leq O D c$ no biofilm production $O D c<O D \leq 2 \times O D c$ weak biofilm production $2 \times$ ODc $<O D \leq 4 \times$ ODc moderate biofilm production $4 \times$ ODc $<O D$ strong biofilm production.

\subsection{Indirect mechanism}

\subsubsection{Qualitative and quantitative estimation of ammonia production}

The bacterial isolates were inoculated in $10 \mathrm{ml}$ of peptone water broth and incubated at $28^{\circ} \mathrm{C}$ for 5 days. Then, Nessler's reagent ( $\left.0.5 \mathrm{ml}\right)$ was added in every tube. The color of the media changed from brown to yellow, which indicates the presence of ammonia production, and its OD was measured at $450 \mathrm{~nm}$ using a spectrophotometer (6405 UV-Visible, JENWAY) following ${ }^{29}$. The concentration of ammonia was estimated using the well-known curve for ammonium sulfate for concentrations in the 0.1-1 $\mathrm{mol} / \mathrm{ml}$ range.

\subsubsection{Qualitative screening of hydrogen cyanide production}

Hydrogen cyanide production was evaluated using the qualitative technique described by ${ }^{30}$. Bacterial isolates are streaked on nutrient broth supplemented with glycine $(4.4 \mathrm{~g} / \mathrm{l})$, Whatman paper no. 1 (soaked in $2 \%$ of $\mathrm{Na} 2 \mathrm{CO} 3$ in $0.05 \%$ picric acid) is put on the peak of the plate which is then sealed with Para film 
and incubated at $28^{\circ} \mathrm{C}$ for 6 days. The color of the filter paper strips change from yellow to light brown, brown, and brick red was recorded as weak $(+)$ moderate $(++)$, or strong (+++) reaction, respectively. If there is no change in color, it is recorded as a negative (-) reaction.

\subsection{Evaluation of PGPB on growth of Arabidopsis plants}

\subsubsection{Screening PGPB isolates for plant growth promotion on Arabidopsis thaliana}

In this study, Arabidopsis thaliana seed wild type ecotype Col-0 were purchased by the Institute for Scientific and Technological Research of San Luis Potosi, (IPICYT), Mexico from Ohio University, Arabidopsis Biological Resource Center. The stock is conserved in IPICYT laboratory, and seed is harvesting every year to refresh and get new more seeds. Then, the experiment was performed following IPICYT guide lines. The seeds were surface-sterilized with $20 \%$ sodium hypochlorite and centrifuge at $1500 \mathrm{rpm}$ for 7 minutes, rinsed five timeswith sterile deionized water at $1500 \mathrm{rpm}$ for 5 minutes and vernalized for 2 days at $4^{\circ} \mathrm{C}$ in thedark. ${ }^{31}$. The vernalized seeds were placed on bipartite Petri dishes containing $0.5 \%$ strength Murashige-Skoog (1/2x MS) medium (Sigma-Aldrich, St.Louis, MO) with $0.8 \%$ agar and $1.5 \%$ sucrose, and the plates were incubated for 2 days $\left(16 \mathrm{~h}\right.$ light and $8 \mathrm{~h}$ dark at $\left.22^{\circ} \mathrm{C}\right){ }^{31}$.Two days before the plant experiments, bacterial strains were cultured on Nutrient broth and grown overnight. Bacterial cells were counted by hemocytometer and diluted to $8 \times$ $10^{8} \mathrm{CFU} / \mathrm{ml}$. and fifteen microliters of a bacterial cell suspension were placed in the direct interaction (Ba-MS), and in the split interaction (Ba/MS) of MS medium. Plates were sealed with plastic film and incubated in the growth chamber as described above. The fresh shoot weight, root length and lateral root per seedling were measured 15 days after planting. The assay was in five replication for each treatment.

\section{Results}

\subsection{Diversity and characterization of Rhizosphere and Endophytic bacteria}

A total of 60 bacteria were isolated from different parts of pepper plant from the Eastern parts of Ethiopia (table 1) among them 7 were from roots, 6 were from stem, 5 from leaves, 4 from fruits and 38 from rhizosphere of pepper plants. In other words from 60 isolates, 38 were from the rhizosphere (63.33\%) and 22 were from endophytic isolates (36.66\%). Gram staining test on those isolates confirmed that $95 \%$ of those isolates had been gram-negative and the rest of $5 \%$ isolates were gram-positive. Sixty morphologically different bacterial endophytes and rhizosphere isolated from the pepper grow on Nutrient agar, and Blood base agar media. The bacterial endophytes and rhizosphere isolated from the root, stem leaves and rhizosphere of pepper were abbreviated as AAURE, AAUSE, AAULE and AAUR respectively. Preliminary screening for the antagonistic potential of the bacterial isolates were done by dual culture plate assay on PDA medium that supported the growth of both the bacterial isolates and the pathogen. Out of the total 60 bacterial isolates 20 (33.3\%) were selected based on dual culture plate assay, plant growth promoting effect and other parameters as shown in the table-2 and 3 below. Among the 20 antagonistic bacteria, AAULE51 (un identified) isolates were dominant followed by isolates of AAUSR23 (Enterobacter hormaechei), AAUFE29 (Rhizobium sp.), and AAULE41 (Pseudomonas flourscence). The antagonistic activity of mycelial growth inhibition of Phytophthora capsici was recorded from 54.8-94.65\% and these were selected for further study.

Table.1 Endophytic and hizosphere bacteria isolated from pepper

\begin{tabular}{|llllllll|}
\hline $\begin{array}{l}\text { Characteristics of endophytic and } \\
\text { rhizosphere bacteria }\end{array}$ & \multicolumn{2}{l}{ Pepper } & & & & & \\
\hline $\begin{array}{l}\text { No of endophytes \& rhizosphere isolated } \\
\text { from pepper plants }\end{array}$ & Root & Stem & Leaf & Fruit & Rhizosphere soil & Total \\
\cline { 2 - 7 } & 7 & 6 & 5 & 4 & 38 & 60 \\
$\begin{array}{l}\text { Bacterial isolates with antagonistic activity } \\
\text { againstP.capsici }\end{array}$ & 1 & - & 2 & 3 & 14 & 20 \\
\hline
\end{tabular}

Table. 2 Antagonistic potential of bacterial isolates from different parts of pepper in dual culture plate assay 


\begin{tabular}{|llll|}
\hline Source & Bacterial strain & Isolates code & \% of inhibition zone \\
\hline Pepper-Rhizospher & Uncultured Thermoprotei archaeon & AAUSR1 & $26.81 \pm 10.14$ \\
\hline Pepper - Rhizospher & Bacillus thruringienesis & AAUSR2 & $21.86 \pm 10.14$ \\
\hline Pepper - Rhizospher & Stenotrophomonas maltophilia & AAUSR4 & $10.27 \pm 10.14$ \\
\hline Pepper - Rhizospher & Achromobacter denitrifican & AAUSR5 & $14.03 \pm 10.14$ \\
\hline Pepper - Rhizospher & Stenotrophomonas maltophilia & AAUSR7 & $11.85 \pm 10.14$ \\
\hline Pepper - Rhizospher & Comamonas testostroni & AAUSR8 & $14.8 \pm 10.14$ \\
\hline Pepper - Root & Pantoea cheilomeans & AAURE11 & $12.56 \pm 10.14$ \\
\hline Pepper - Rhizospher & Seracia marcenscec & AAUSR15 & $18.47 \pm 10.14$ \\
\hline Pepper - Root & Pseudomonas flourscence & AAURE16 & $8.13 \pm 10.14$ \\
\hline Pepper - Fruit & Entrobacter xiangfangensis & AAUFE17 & $25 \pm 10.14$ \\
\hline Pepper - Fruit & Bacillus cerus & AAUFE18 & $16.1 \pm 10.14$ \\
\hline Pepper - Rhizospher & Pseudomonas stutzeri & AAUSR19 & $12.77 \pm 10.14$ \\
\hline Pepper - Rhizospher & Enterobacter asburiae & AAUSR22 & $22.04 \pm 10.14$ \\
\hline Pepper - Rhizospher & Enterobacter hormaechei & AAUSR23 & $63.24 \pm 9.3$ \\
\hline Pepper - Fruit & Rhizobium sp & AAUFE29 & $57.83 \pm 9.7$ \\
\hline Pepper - Leaf & Pseudomonas florecense & AAULE41 & $54.81+9.7$ \\
\hline Pepper - Rhizospher & Aeromonas hydrophilia/caviae & AAUSR43 & $10.56 \pm 10.14$ \\
\hline Pepper - Stem & Rhizobium radiobacter & AAUSE44 & $16.82 \pm 10.14$ \\
\hline Pepper - Rhizospher & Enterobacter cloacae & AAUSR48 & $17.2 \pm 10.14$ \\
\hline Pepper - Leaf & Unidentified & AAULE51 & $94.65 \pm 9.3$ \\
\hline
\end{tabular}

Table.3. Twenty bacterial isolates selected based on the above criteria

\begin{tabular}{|c|c|c|c|c|c|c|c|c|c|c|c|c|}
\hline Isolates & AASR1 & AAUSR2 & AAUSR4 & AAUSR5 & AAUSR7 & AAUSR8 & AAURE13 & AAUSR15 & AAURE16 & AAUFE17 & AAUFE18 & AAUSI \\
\hline IAA & + & + & + & + & + & - & + & + & + & + & - & - \\
\hline $\mathrm{NH} 3$ & - & - & + & - & - & - & + & + & - & - & - & - \\
\hline $\begin{array}{l}\text { P- } \\
\text { solublization }\end{array}$ & - & - & + & - & - & - & + & + & - & - & - & - \\
\hline Biofilm & - & - & - & + & + & - & + & + & - & + & + & + \\
\hline $\mathrm{HCN}$ & + & - & - & + & - & - & + & - & - & + & - & - \\
\hline Protease & - & & + & - & - & - & + & + & - & + & - & + \\
\hline Celulase & + & + & - & - & + & + & + & + & - & + & - & + \\
\hline Chitinase & + & + & - & - & - & - & - & + & + & - & - & + \\
\hline $\begin{array}{l}\text { Drought } \\
\text { resistant }\end{array}$ & - & + & + & + & - & - & + & + & - & - & - & - \\
\hline $\begin{array}{l}\text { Total } \\
\text { percentage }\end{array}$ & 44 & 44 & 55.6 & 44 & 33 & 11 & 89 & 89 & 22 & 55.5 & 11 & 44 \\
\hline
\end{tabular}

\subsection{Biochemical, Molecular and physiological characterization}

We obtained a total of 60 rhizospher and endophyte bacterial strains from the tissue and rhizosphere of pepper plants. Twenty isolates were selected based on their ability to produce IAA, phosphate solublization, biofilm, and ammonia and hydrogen cynide production and show in vitro antagonism against Phytophthora capsici and Fusarium sp. pathogens in a preliminary screening. All 20 isolates were tested to the Gram staining, citrate, catalase, indole and oxidase tests (Table 4).

Phylogenetic trees of three gram positive and seven gram negative bacterial strains constructed from 16S rRNA sequences showed that the selected isolates were mainly members of genus Bacillus, Pseudomonas, Rhizobium, Enterobacter, Serracia, and Pantoea (Fig. 9a \&b). The sequences of the isolates AAUSR1, 
AAUSR2, and AAUSR18 showed 100\% similarity. Isolate AAULE41 had 98\% homology with Pseudomonas flourscence. Isolate AAUSR29 was identified as Rhizobium sp. with Gen Bank accession number MW89263. Isolates AAUSR16 showed $98 \%$ sequence homology with Serracia marcescens (Fig. 9b).

Table 4

Biochemical characterization of 20 selected endophytic and rhizosphere bacterial isolates ha

\begin{tabular}{|c|c|c|c|c|c|c|c|c|c|c|c|c|}
\hline $\begin{array}{l}\text { Biochemical } \\
\text { tests }\end{array}$ & AAUSR1 & AAUSR2 & AAUSR4 & AAUSR5 & AAUSR7 & AAUSR8 & AAURE13 & AAUSR15 & AAURE16 & AAUFE17 & AAUFE18 & AAUS \\
\hline $\begin{array}{l}\mathrm{H}_{2} \mathrm{~S} \\
\text { production }\end{array}$ & - & - & - & + & + & - & - & - & - & - & - & - \\
\hline $\begin{array}{l}\text { Gas glucose } \\
\text { production }\end{array}$ & - & - & - & - & & - & - & + & - & - & - & - \\
\hline Lactose & - & - & - & - & & - & - & - & - & - & - & - \\
\hline $\begin{array}{l}\text { Citrate } \\
\text { utilization }\end{array}$ & - & - & - & + & + & + & + & + & - & + & - & + \\
\hline Oxidase & - & - & - & + & - & + & + & & & - & + & + \\
\hline Urease & - & - & + & + & + & - & - & + & - & - & - & - \\
\hline Indole & + & + & + & + & + & - & + & + & + & + & - & - \\
\hline Glycerol & - & - & - & - & - & - & - & - & - & & + & \\
\hline Catalase & + & & + & + & + & + & + & + & + & + & + & + \\
\hline
\end{tabular}

't' Positive for biochemical reaction; '-' Negative for biochemical reaction

\subsection{Plant Growth promoting traits}

\subsubsection{IAA Production}

Twelve isolates out of 60 rhizosphere and endophytic bacteria were produced IAA in ordinary medium (Nutrient agar); while when supplemented with different concentrations of L-tryptophan, medium 5 additional isolates were produced IAA. The culture supernatant changed to red color after the addition of the Salkowski's reagent (Fig. 1a, table 1). Isolates of AAUSR7, AAUSR15, AAURE16, AAUSR23, AAULE41, AAUSR43, AAUSE44, and AAUSR48 produced more than $40 \mu \mathrm{g} / \mathrm{ml}$ of IAA when supplemented with L-tryptophan (Fig. 1b). The maximum production of IAA (159 $\mu \mathrm{g} / \mathrm{ml})$ was attained by utilizing $35.5 \%$ of Itryptophan, when medium was supplemented with $400 \mu \mathrm{g} / \mathrm{ml}$ concentration of I-tryptophan as a precursor (Fig. 1c).

\subsubsection{Phosphate solublization}

\subsubsection{Qualitative and quantitative P-solubilization}

Qualitative solubilization of phosphorus was estimated the clear/halo zones around the bacterial colonies on Pikovskaya agar media and phosphorus solubilizing media was calculated. Only 11 isolates out of total 60 isolates showed zone of phosphate solublization on Pikovskaya agar plate. From these two isolates were found to have more than $10 \mathrm{~mm}$ phosphate solubilizing index (PSI). Maximum PSI was observed by AAU51 (14.3 $\pm 0.9^{\mathrm{a}}$ ) followed by AAU29 $\left(11.7 \pm 0.9^{b}\right)$ (Fig 2a). Quantitative estimation of phosphate solublization is shown in (Fig. 2b). Out of 11 phosphate solublizer on pikovskaya broth, only 5 showed phosphate solublization of $40 \mu \mathrm{g} / \mathrm{ml}$ or more on quantitative phosphate solublizaton. Consequently, as shown in Fig. $2 \mathrm{c}$, it can be seen that the increased concentration of the P-solublized in the pikovskaya liquid medium by bacterial isolate is in accordance with the increase of the PSI values, with the correlation value of 0.79

\subsubsection{Biofilm formation}

\subsection{3 .1 Plate Method}

Among the total 60 isolates, 31 and from 20 selected 15 bacterial isolates were produced biofilm both in tube and slide methods (Fig. $3 a$ \&b). Biofilm detection from endophytic and rhizosphere bacteria was done by Congo red agar method. It was observed that the strains produced white colored colonies on CRA medium, were negative while positive isolates produced black colored colonies, which was a typical indication for the production of biofilm (Fig. 3a). This study has been reported that the nutrient composition of the CRA medium in particular, supplementation of various sugars were greatly influenced the colony morphology as well as biofilm formation efficiency of the rhizosphere and endophytic bacteria.

\subsection{3 .2 Tube method}

In this method, the biofilm formation was seen by the formation of a visible thick film inside the wall of the tube and bottom of the tube. The isolates were showed thick film inside the bottom of the glass tube indicating strong biofilm production, while other isolates did not show the formation of biofilm in the glass tubes (Fig. 3b). And its optical density after washed with methanol were measured.16 isolates had strong biofilm production (+++) OD (570nm), 1 isolate showed moderate biofilm production (++) whereas, 12 isolates were showed weak biofilm formation (+).

\subsubsection{Ammonia production}

All 60 bacterial isolates were showed production of ammonia in peptone water. Ammonia produced by different bacterial isolates is showed in Fig. 6 . AAULE51 and AAUSR1 isolates produced maximum ammonia, which was $121.9 \mu \mathrm{mol} / \mathrm{ml}$ (OD 450). The 9 isolates produced more than $50 \mu \mathrm{mol} / \mathrm{ml}$ (OD 450$)$ 
of ammonia.

\subsubsection{Qualitative and quantitative screening of $\mathrm{HCN}$ production}

Sixty isolates recovered from different locations and different parts of pepper were tested for their ability to produce hydrogen cyanide (HCN). Only 8 isolates were able to produce HCN. The $8 \mathrm{HCN}$ producing isolates were isolated 4 from rhizosphere soil, and 4 from endophytic of pepper plants grown in Eastern Ethiopia (AAUSR10, AAURE12, AAURE13, AAUSR15, AAUSR20, AAUSR22, AAUSR41 and AAUSR51. A strong (+++) HCN production was recorded by the isolate AAURE13, AAUSR22, and AAULE41; while a moderate (++) reaction was recorded by AAURE12, AAUSR20, and AAULE51. A weak (+) reaction was recorded by AAUSR1 and AAUSR15 (Table 5 and Fig. 8). Quantitative assay of HCN production by bacterial isolates showed that isolates AAURE13 and AAURE41 were produced a maximum absorbance value of $\mathrm{HCN}$ ( 0.13 and 0.23 respectively), followed by AAUSR22, AAURE51, and AAUSR12 which recorded absorbance values of $0.086,0.063$, and 0.057$)$, respectively. The lowest absorbance were recorded by AAUSR10 (0.032 (Fig. 5)

Table 5

Quantitative assay of HCN produced by bacterial isolates at 600

\begin{tabular}{|c|c|c|c|c|c|c|c|c|c|c|c|c|}
\hline $\begin{array}{l}\mathrm{HCN} \\
\text { producing } \\
\text { isolates } \\
\text { code }\end{array}$ & AASR1 & AAUSR2 & AAUSR4 & AAUSR5 & AAUSR10 & AAUSR12 & AAURE13 & AAUSR15 & AAURE16 & AAUFE17 & AAUFE20 & AAUSF \\
\hline $\begin{array}{l}\mathrm{HCN} \\
\text { producing } \\
\text { reaction }\end{array}$ & - & - & - & - & + & ++ & +++ & + & - & - & ++ & - \\
\hline
\end{tabular}

\subsubsection{Plant Growth Stimulation Assay of Selected Bacterial Isolates on Arabidopsis thaliana (Col-0) Plant in a bipartite petridish}

To determine the plant promotion effect of selected Bacterial isolates on Arabidopsis which is grown on MS culture media with Arabidopsis plant, two experiments were analyzed such as in the direct interaction (Bacteria-Arabidopsis on MS) and split interaction (Bacteria/Arabidopsis on MS). Physiological parameters at 10 days post inoculation (dpi), such as fresh weight, main root length, and lateral root number of plants, were used to evaluate the effect of bacteria on Arabidopsis growth (Fig. 8a, b, c \& d). All isolates were showed an increment in the Arabidopsis fresh weight. While isolate AAUFE29 in the split system stimulated significantly the plant growth which reached double the fresh weight of un-inoculated control plants (Fig. 8a). In the main root length, there was no significant difference observed in both split and direct interaction systems in comparison with un-inoculated control (Fig, 8b). In respect to the lateral roots, in all isolates except AAUSR23 significant difference was observed (Fig, 8c) both in a split and direct system. Isolate (AAULE 51-MS) was achieved nearly 20.5 lateral roots in contrast to the 5.3 lateral roots in the control in the absence of bacterial isolates.

\section{Discussion}

Rhizobacteria and endophyte bacteria coloniz the different parts of the plant in various ways; by controlling the plant diseases, by antagonism and by promoting plant growth parameters ${ }^{32}$. Rhizosphere soil and endophytes play an important role in recruiting and maintaining bacterial antagonists ${ }^{33}$. Rootassociated bacteria often shows plant beneficial features such as plant growth promotion and the ability of suppressing plant pathogens acting as biocontrol agents ${ }^{34}$. The diversity of endophytic, and rhizosphere bacteria are grouped into cultivable and non-cultivable microbes. Only cultivable microbes can be used to formulate bio fertilizer for further study, therefore the focus of the study was only with cultivable microbes. Bacterial diversity on different parts of pepper plants can be obtained by culture analyses ${ }^{35}$. Culturing on different media was applied in the present study to investigate the diversity and isolate antagonistic and PGPB endophytic and rhizospheric bacteria from pepper plants against $P$. capsici and its plant growth-promoting effect on Arabidopsis plant. The screening of 60 endophytic and rhizospheric bacteria on the basis of their antagonistic potential against oomycetes and its effects on plant growth subsequent identification on a vitek compact2 and 15 rRNA) resulted in diversity of different groups of bacteria comprising 13 different genera and 11 unknown strains. In the present study, sixty rhizo and endophytic bacterial strains were recovered from chilli rhizosphere, root, stem, leaf and fruits, majorly belonged to the genera Entrobacter and Pseudomonas. Concerning the isolated bacteria, $11.67 \%$ were from roots, $63.33 \%$ from the rhizosphere, $8.3 \%$ from leaves and $11 \%$ from stem. Previous studies also report on various biocontrol potential of bacteria belonging to the genera Pseudomonas and Bacillus ${ }^{36}$, Bacillus subtlis and Actinomycetes ${ }^{37}$ being the most common bacterial groups showing in pepper plants. Bacterial colonization appeared to be abundant in the rhizosphere pepper plants, which may be a reflection of a primary site for bacterial nutrients. Antibiotic production may be one of the mechanisms used by these bacterial isolates to dominate the host by preventing other potential colonizers ${ }^{38}$. The preference of bacteria for the rhizosphere reflects the presence of high levels of nutrients in the rhizosphere and the capability of the nutrients to support higher bacterial growth and metabolism in rhizosphere soils compared with other tissues ${ }^{39}$. The results showed that some of the plant growths promoting bacteria revealed multiple plant growths promoting traits and disease suppressing ability in in vitro. PGPR has often been found to reveal multiple modes of action, including biological control ${ }^{40}$. Presently, from all 60 bacterial isolates $(n=8,13.3 \%)$ of endophytic bacteria and $(n=12,20 \%)$ of rhizospheric bacteria that were antagonists against oomycetes and Fusarium as well as has plant growth prompting effects. ${ }^{41,42}$ previously studied on bacterial antagonists and found that $27.5-62.6 \%$ are antagonistic against the common plant pathogenic fungi like Phythophotora capsici, Rhizoctonia solani, Py. ultimum, Fusarium oxysporum, and Botrytis cinerea. This may be because we used only Phytophthora capsici and Fusarium spp as potential organisms, while in the previous study the initial screening included many potential pathogens.

The antagonistic effect of the bacterial strains used as biological control for $P$. capsici ${ }^{43}$. Initially, from sixty bacterial strains, twenty were screened for antagonism against $P$. capsici. All the twenty tested bacterial strains showed varied levels of antagonistic potential. In this study results showed that four bacterial isolates, i.e., AAUSR23- Enterobacter hormaechei, AAUFE29- Enterobacter sp. V.H.18, AULE41-Pseudomonas fluorescence and AAULE51-un identified showed $>52.5 \%$ mycelial growth inhibition of Phytophthora capsici. ${ }^{36}$ studied the antagonistic effects of bacterial strains and found that, out of fifteen tested 
rhizospheric bacteria, five bacterial strains showed $>70 \%$ of antagonistic potential against P.capsici. In other study from 48 threeisolates were found to control P.capsiciboth in vivo and in vitro ${ }^{44}$. Bacillus amyloliquefaciens also, have been reported as both plant growth promoters and biocontrol agents against soilborne pathogens including Fusarium wilt of banana and potato dry rot caused by Fusarium sp. ${ }^{45}$. In our study 20 isolates showed both plant growth promotors and biological controls against $P$. capsici. From this isolate Enterobacter hormaechei, Entrobacter sp. V.H.18, Pseudomonas florecense, and AAULE51 -Unidentified that showed highest antagonistic effect against $P$. capsici and plant growth promotion activity were selected for further study.

The role of plant growth promotion microbes can be grouped into direct and indirect. Direct mechanisms include nitrogen fixation, phosphate solubilization, biofilm production, and IAA production while indirect mechanisms include cell wall degrading enzyme production, ammonia production, HCN production and antibiosis $^{46}$.

The direct growth promoting characters of beneficial bacteria are the ability to produce biofilm formation, solubilize phosphate, and production of Indole acetic acid. These traits increase the available nutrients in the soil, which the plant can absorb for growth ${ }^{47}$. Most of the tested bacteria showed multiple PGP traits which help to growth promotion and disease reduction ability of PGPB. The multiple modes of action have been researched to be the main reasons for the plant growth promotion and disease suppressing potential of PGPR ${ }^{48}$. It is essential to screen the potential of rhizo bacterial and endophytic strains for their plant growth promotion characters to obtain the desired benefits of disease management, and plant growth promotions. In this study, four bacterial strains with better antagonism effect against $P$. capsici and plant growth promotion traits were selected.

Indole-3-acetic acid (IAA) is a secondary metabolite, and its production in bacterial agents is generally described based on their ability to use tryptophan supplemented in the growth medium, which is the major precursor of IAA biosynthesis via the indole pyruvic acid (IPA) pathway ${ }^{49}$. IAA supports root development, elongation, and proliferation and helps plants to take up water and nutrients from the soil ${ }^{50}$. L-Tryptophan is commonly considered as an IAA precursor because its addition to IAA producing bacterial culture enhances IAA biosynthesis ${ }^{51} .{ }^{52}$ reported that all tested endophytic bacterial strains had the ability to produce IAA in the absence and presence of tryptophan. In the present study from 17 IAA producing isolates, 12 had the ability to produce IAA in the absence of L-tryptophan. The maximum production of IAA was recorded in the medium supplemented with $400 \mu \mathrm{g} / \mathrm{ml}$ tryptophan for isolate AAUSR17, AAUSR 43, AAUSE 44, $200 \mu \mathrm{g} / \mathrm{ml}$ for isolate AAURE16 and AAUSR48 (Fig. 1b ).

The plant growth is affected by low pH since the concentrations of metals like Al $3+$ and $\mathrm{Mn} 2+$ increase in the soil solution, and able to reach toxic levels. It is known that soil pH and metal cations might disturb many processes arising in the rhizosphere. The impact of different levels of pH (4.28-8.5) on media after 7 days incubation was determined. The maximum amount of IAA was produced when the pH of the culture medium was 6.44 and 6.22 for isolates AAUSR43 and AAUSR7 (Fig. 1b). ${ }^{51}$ have reported br12, br2, and br3 for elaborated high levels of IAA production in a medium having pH $8 .{ }^{53}$ studied on IAA production by Streptomyces sp. and reported that $\mathrm{pH} 7.0$ was suitable for maximum IAA production. ${ }^{54}$ studied on IAA producing bacteria and reported that most of the organisms are gram-negative. ${ }^{55}$ reported a few known gram positive bacillus strains to produce IAA. Present study showed that from 17 IAA producing strains 16 were gram-negative and 1 gram positive. Except for isolate AAURE16 (Pantoea cypri pedii) and AAULE41 (Pseudomonas florecense) the IAA production of I-tryptophan increased with increasing I-tryptophan concentration but the utilization of I-tryptophan decreases with increasing I-tryptophan concentration. This might be due to a change in $\mathrm{pH} .{ }^{56}$ reported that the optimal IAA production and bacterial growth were at neutral $\mathrm{pH}$, therefore acidic and alkaline conditions may affect the production of IAA as well as the growth of an organism. ${ }^{56}$ also on IAA production and I-tryptophan utilization and found that the IAA production and utilization of I-tryptophan decreased with increasing I-tryptophan concentration.

Phosphate solubilization bacteria is one of the very crucial trait of plant growth promotion that solubilizes insoluble phosphate and making it available for plants. It has been found that $\mathrm{P}$ is important for plant growth, and its deficiency limits plant growth. Although synthetic fertilizers are added to the soils, because of the immobilization of phosphorus, plants can only use a small amount of phosphatic fertilizer. Therefore, the choice of highly efficient phosphate solubilizing bacteria is very important; it will practically increase phosphorous in the rhizosphere and tissue of plants. ${ }^{57}$ reported that the isolates which solubilize tri-calcium phosphate (TCP) in a liquid and solid medium capable for produce organic acids making the $\mathrm{pH}$ of the medium acidic.

In the present study from 60 isolates, 11 strains showed phosphate solubilization and almost all of the isolates that can solubilize TCP showed drop in the pH of the medium when compared to the control. The decrease in the $\mathrm{pH}$ is supported by the production of different organic acids by consumption of sugars ${ }^{58}$.

${ }^{59}$ also studied on phosphate solubilization of potential rizosphere fungi and reported that the maximum pH decrease was recorded from the 5 th and 10 th days of incubations by the most fungal isolates but was later increased or nearly constant in all liquid culture. From the nine isolates, the biggest decrease of $\mathrm{pH}$ in the medium was from an original value of 7.0 to $\mathrm{pH}$ values $4.00,4.05,4.13$, and 4.23 for the isolates JUHbF60, JUCaF37, JUHbF95, and JUFbF59, respectively, 10 days after incubation. However, no decrement of pH was found in the last 15-20 days of incubation in PVK liquid medium. In this study the maximum pH drop was recorded in the 15th days of incubation by isolate AAUSR15 (from pH 7.00 to 3.7). Further bacterial isolates of AAUSR15 and AAUSR43, AAUSR23 and AAUFE17 showed a significant increment of pH after 5, 10, and 15 days of incubation respectively. An increment of pH could be microorganisms face the lack of nutrients and begin to consume the organic acids as the nutrient sources.

In our study, the concentration of phosphate solubilizing isolates in the PVK medium showed, ranged between $4.25 \pm 0.005 \mu \mathrm{g} / \mathrm{ml}$ to $86.75 \pm 0.005 \mu \mathrm{g} / \mathrm{ml}, 13$ $\mu \mathrm{g} / \mathrm{ml} \pm 0.055 \mu \mathrm{g} / \mathrm{ml}$ to $94.25 \mu \mathrm{g} / \mathrm{ml} \pm 0.055 \mu \mathrm{g} / \mathrm{ml}$ and $11.75 \mu \mathrm{g} / \mathrm{ml} \pm 0.034 \mu \mathrm{g} / \mathrm{ml}$ to $90.5 \mu \mathrm{g} / \mathrm{ml} \pm 0.034 \mu \mathrm{g} / \mathrm{ml}$ after 5,10 and $15 \mathrm{days}$ of incubation respectively. The highest concentration was recorded in isolate AAUFE29 (Enterobacter sp.V.H.18)a t pH of 6.3 after 10 ten days of incubation. ${ }^{60}$ studied on Phosphate solublization in the National Botanical Research institutes on phosphate growth medium (NBRIP) and found that the concentration of soluble phosphate ranged between $101.91 \mu \mathrm{g} / \mathrm{ml}$ and $174.33 \mu \mathrm{g} / \mathrm{ml} .{ }^{61}$ also studied on the solubilization of TCP and found that the soluble phosphate concentration was ranged from 41.20 to $119.95 \mu \mathrm{g} / \mathrm{ml}$ in the NBRIP medium. The better performance of AAUFE29 (Enterobacter sp. V.H.18) to release the available phosphorus in PVK medium indicates the role played by insoluble phosphate sources to trigger microbial action. 
With regard to the incubation period, the solubilization capacity of the organism was high till 10 days of incubation. The isolate AAUFE 29 (Enterobacter sp.V.H. 18) solubilizes more amount of phosphate during 10 days of incubation, which was readily available and declined later. The decrease in phosphate solubilization after a maximum value might be attributed to the shortage of nutrients in the culture medium and a change in $\mathrm{pH}$. Also, the decrease in soluble $\mathrm{P}$ at 15 days of incubation may be either due to decreased solubilizing activity or increased $\mathrm{P}$ absorption and re-fixation of solubilized phosphorus with metal ions present in the medium. These results are in confirmation with the results observed by ${ }^{62}$, the $\mathrm{P}$ concentration in the liquid medium did not have a sigmoid curve type but with some variabilities, which could be due to cell lysis and phosphorus precipitation brought about by organic metabolites. In our study, the decrease in phosphorus solubilizing concentration for the duration of 5 days of incubation in some phosphate solublizing bacteria as shown in (Fig. 3a) can be recognized as a result of the consumption of accessible phosphorus for growth and development of the bacteria.

Additionally, as shown in Fig. 3b, the increased concentration of the P-solublization in the pikovskaya liquid medium by bacterial isolates is in accordance with the increase of the PSI values, with the correlation and P-value value of 0.79 and $\mathrm{P} \leq 0.0037$ respectively. Also in previous studies where the correlation of $\mathrm{P}$ solubilization and PSI was 0.8963 .

Biofilms are surface-associated microbial cells, enclosed in a self-produced EPS that predominantly contain proteins, polysaccharide, and lipids ${ }^{64}$. ${ }^{65}$ studied on biofilm producing PGPR and reported that they are more effective under field conditions than any planktonic PGPR

In this study, 31 (51.67\%) from 60 bacterial strains isolated from pepper plants were found to form biofilms (Fig. 4Aa, \&b). Among them, 16 (51.8\%) strains showed strong biofilm production. ${ }^{66}$ reported on biofilm production of rhizobacterial strains isolated from rhizosphere of tomato plants, and found that from 78 tasted strains 21 (26.9\%) were found to form biofilms... All these biofilm-producing rhizobacterial strains are nonpathogenic to human and animals based on the hemolytic test using $5 \%$ sheep blood.

Another important PGPR mechanism that indirectly influences plant growth is ammonia production. It accumulates and supply nitrogen to their host plants and promotes plant growth. In this study all the isolates were able to produce ammonia and the highest value of $121.9 \mu \mathrm{mol} / \mathrm{ml}$ were measured for strains AAULE51 and AAUSR1 (Fig. 5). ${ }^{67}$ reported that ammonia produced by plant growth promoting bacteria has been shown to supply nitrogen to their host plants and thus promote root and shoot elongation and their biomass. Bacterial isolates can improve plant development by the production of ammonia through the hydrolysis of urea into ammonia and carbon dioxide. ${ }^{67}$ also reported that the ammonia production by the rhizobacterial isolates was observed in the range of $2.5 \mu \mathrm{mol} / \mathrm{ml}$ to $7.54 \mu \mathrm{mol} / \mathrm{ml}$. About $67 \%$ of bacterial isolates revealed more than $4 \mu \mathrm{mol} \mathrm{ml}^{-1}$ of ammonia production, and strain $\mathrm{AB} 331$ produced the highest amount of ammonia $(7.54 \mu \mathrm{mol} / \mathrm{ml})$. In the present study, the ammonia production by bacterial isolates was observed in the range of $11.72 \mu \mathrm{mol} / \mathrm{ml}$ to $124 \mu \mathrm{mol} / \mathrm{ml}$ ). About $30 \%$ (18 isolates) showed ammonia production of more than $12 \mu \mathrm{mol} / \mathrm{ml}$.

Hydrogen cyanide production are suggested indirect mechanisms of plant growth promotion. HCN is a volatile product which has an antifungal activity. It was believed that initially HCN production play its role in plant growth promotion by suppressing the plant pathogens ${ }^{68}$. However, this idea has recently been changed. It has been supposed that the production of HCN indirectly increases phosphorus availability by chelation and sequestration of metals, and indirectly increases the nutrient availability to the bacteria and host plants ${ }^{69}$. In our study, from the tested bacterial strains eight were positive for HCN production test. Under this study a highest (0.23) HCN production was recorded by the isolate AAULE (Pseudomonas floursence), while a lowest production was recorded by AAUSR10 (Table 5 \& Fig. 6).

Plants and bacteria can interact with one another in a variety of different ways. The interaction may be beneficial, harmful. or neutral for the plant, and sometimes the impact of a bacterium may vary as the soil conditions change ${ }^{70}$. In nature, plants are not isolated organisms, so that during their evolution they have adjusted to interact with diverse communities of symbiotic, beneficial, and pathogenic microorganisms ${ }^{71}$. Plant growth-promoting bacteria are naturally existing in soil and tissue that aggressively colonize plant roots and plant tissue and benefit plants by giving growth promotion. Inoculation of crop plants with certain strains of PGPB at an early stage of development improves biomass production through direct effects on root and shoots growth 72 .

Microorganisms that can strongly influence plant performance, for example, by modulating nutrient uptake and thereby either enhance or decrease nutrient availability. Although many studies have been studied with the beneficial plant-microbe interaction, relatively few have provided a more thorough description of the effects on the plant by the interaction when it involves PGPB. In this study, we used Arabidopsis as a model system to investigate the effect on phenotypic properties, plant growth regulation, and root development by using four bacterial isolates which provide disease suppression. A positive effect was observed with growth promotion for Arabidopsis after treated with bacterial isolates. After inoculation of bacteria, the growth of primary roots, fresh weight of Arabidopsis, and number of lateral roots were showed increment when compared to control experiment (growth without the cultivation of bacteria) after 14 days of inoculation. The fresh weight of AAUSFE29 (Enterobacter sp.V.H.18) on a bi-partite Petri dish reached an approximately 2-fold increase. This suggests that bacterial metabolites might synthesis of bioactive VOCs and privileged accumulation of carbon dioxide. In the present study also, we evaluated the effect of potential bacterial isolates on Arabidopsis thaliana growth when the bacteria was grown in an appropriate bacterial culture medium, such as nutrient agar medium. When both bacterial strtains were grown on MS medium, major growth and development of the Arabidopsis plants were observed in comparison to the control condition. Particularly, the number of lateral roots was higher in the MS medium of bacterial Arabidopsis interaction experimental condition with both bacterial isolates. Microorganisms produce a broad spectrum of volatile organic compounds with various functions in plants such as defense, growth, variety of root building, and in microbe-plant communication ${ }^{73}$.

\section{Conclusion}

Out of sixteen bacterial isolates, four efficiently suppressed the mycelial growth of pathogenic Phytophthora capsici in dual culture assays in vitro. Bacterial isolates with strong anti-fungal potential were found positive for HCN, catalase test, Indole acetic acid (IAA), ammonia and phosphate production. This study shows the taxonomic diversity and existence of antagonistic and plant growth endophytic and rhizosphere bacteria with different physiological and

Page $10 / 19$ 
biochemical capabilities, which may give a basis for the isolation of new potent biocontrol agents of oomycete plant pathogens. Furthermore, it appears that pepper plants can be an important source of endophytic and rhizosphere bacteria that induce pepper plant growth promotion and defense against pepper pathogens. Future studies will focus on AAULE51 (unidentified) strain regarding development as a commercial biocontrol agent and determination of the structure of antibiotic compounds, and also to confirm the significant role of native endophyte and rhizobacteria for the control of soil-borne oomycetes and the possible use of this potential isolates in bio-fertilizers and bio-fungicides production. Additional studies regarding field applications and bio formulations are in progress.

\section{References}

1 Paungfoo-Lonhienne, C. et al. Nitrogen fertilizer dose alters fungal communities in sugarcane soil and rhizosphere. Sci. Rep. 5, 8678 (2015).

2 Qasim, S., Shakir, K. \& Al-Shaibani, A. Isolation, screening and production of phytate degrading enzyme (phytase) from local fungi isolate. Iraqi Journal of Agricultural Science 47, 121-128 (2016).

3 Gamez, R. et al. Screening, plant growth promotion and root colonization pattern of two rhizobacteria (Pseudomonas fluorescens Ps006 and Bacillus amyloliquefaciens Bs006) on banana cv. Williams (Musa acuminata Colla). Microbiol. Res. 220, 12-20 (2019).

4 Chenniappan, C. et al. Biocontrol efficiency of native plant growth promoting rhizobacteria against rhizome rot disease of turmeric. Biol. Control 129, 55-64 (2019).

5 La Torre-Ruiz, D. et al. Effect of plant growth-promoting bacteria on the growth and fructan production of Agave americana L. Braz. J. Microbiol. 47, 587-596 (2016).

6 Naseem, H., Ahsan, M., Shahid, M. A. \& Khan, N. Exopolysaccharides producing rhizobacteria and their role in plant growth and drought tolerance. J. Basic Microbiol. 58, 1009-1022 (2018).

7 Ghosh, D., Gupta, A. \& Mohapatra, S. A comparative analysis of exopolysaccharide and phytohormone secretions by four drought-tolerant rhizobacterial strains and their impact on osmotic-stress mitigation in Arabidopsis thaliana. World Journal of Microbiology and Biotechnology 35, 90 (2019).

8 Chung, E. J. et al. Bacillus oryzicola sp. nov., an endophytic bacterium isolated from the roots of rice with antimicrobial, plant growth promoting, and systemic resistance inducing activities in rice. The Plant Pathology Journa/31, 152 (2015).

9 Olanrewaju, O. S., Glick, B. R. \& Babalola, O. O. Mechanisms of action of plant growth promoting bacteria. World Journal of Microbiology and Biotechnology 33, 197 (2017).

10 Compant, S., Duffy, B., Nowak, J., Clément, C. \& Barka, E. A. Use of plant growth-promoting bacteria for biocontrol of plant diseases: principles, mechanisms of action, and future prospects. Appl. Environ. Microbiol. 71, 4951-4959 (2005).

11 Rosenblueth, M. \& Martínez-Romero, E. Bacterial endophytes and their interactions with hosts. Mol. Plant-Microbe Interact. 19, 827-837 (2006).

12 WINE, C. M. G. I. Enhancement of the fertilizer value of rock phosphate engineered through phosphate-solubilizing bacteria. Ecol. Eng. 15, 27-39 (2000).

13 Vandenkoornhuyse, P., Quaiser, A., Duhamel, M., Le Van, A. \& Dufresne, A. The importance of the microbiome of the plant holobiont. New Phytol. 206, 1196-1206 (2015).

14 Bakhshandeh, E., Rahimian, H., Pirdashti, H. \& Nematzadeh, G. A. Phosphate solubilization potential and modeling of stress tolerance of rhizobacteria from rice paddy soil in northern Iran. World Journal of Microbiology and Biotechnology 30, 2437-2447 (2014).

15 Lee, B., Lee, S. \& Ryu, C.-M. Foliar aphid feeding recruits rhizosphere bacteria and primes plant immunity against pathogenic and non-pathogenic bacteria in pepper. Ann. Bot. 110, 281-290 (2012).

16 Ortolani, M. B., Viçosa, G. N., Beloti, V. \& Nero, L. A. Screening and enumeration of lactic acid bacteria in milk using three different culture media in Petrifilm ${ }^{\mathrm{TM}}$ Aerobic Count plates and conventional pour plate methodology. J. Dairy Res. 74, 387-391 (2007).

17 Yang, R., Fan, X., Cai, X. \& Hu, F. The inhibitory mechanisms by mixtures of two endophytic bacterial strains isolated from Ginkgo biloba against pepper phytophthora blight. Biol. Contro/ 85, 59-67 (2015).

18 Amplify, B.-S. P. P. T. Design and Evaluation of Useful. Appl. Environ. Microbio/ 64, 795 (1998).

19 Glick, B. R. The enhancement of plant growth by free-living bacteria. Can. J. Microbiol. 41, 109-117 (1995).

20 Gordon, S. A. \& Weber, R. P. Colorimetric estimation of indoleacetic acid. Plant Physiol. 26, 192 (1951).

21 Ghosh, S. \& Basu, P. Production and metabolism of indole acetic acid in roots and root nodules of Phaseolus mungo. Microbiol. Res. 161, 362-366 (2006). 

strains. Biocatalysis and Agricultural Biotechnology 16, 285-292 (2018).

23 Murphy, J. \& Riley, J. P. A modified single solution method for the determination of phosphate in natural waters. Anal. Chim. Acta 27, 31-36 (1962).

24 Freeman, D., Falkiner, F. \& Keane, C. New method for detecting slime production by coagulase negative staphylococci. J. Clin. Pathol. 42, 872-874 (1989).

25 Kaiser, T. D. L. et al. Modification of the Congo red agar method to detect biofilm production by Staphylococcus epidermidis. Diagn. Microbiol. Infect. Dis. 75, 235-239 (2013).

26 Mathur, T. et al. Detection of biofilm formation among the clinical isolates of staphylococci: an evaluation of three different screening methods. Indian J. Med. Microbiol. 24, 25 (2006).

27 Christensen, G. D. et al. Adherence of coagulase-negative staphylococci to plastic tissue culture plates: a quantitative model for the adherence of staphylococci to medical devices. J. Clin. Microbiol. 22, 996-1006 (1985).

28 Stepanović, S. et al. Quantification of biofilm in microtiter plates: overview of testing conditions and practical recommendations for assessment of biofilm production by staphylococci. APMIS 115, 891-899 (2007).

29 Cappuccino, J. \& Sherman, N. Ammonia production. Microbiology: A Laboratory Manual, 3rd ed.; Benjamin/Cummings Pub Co.: Redwood City, CA, USA, 125-179 (1992).

30 Abd El-Rahman, A. \& Shaheen, H. A. Biological control of the brown rot of potato, Ralstonia solanacearum and effect of bacterization with antagonists on promotion of potato growth. Egyptian J Biol Pest Control 26, 733-739 (2016).

31 Murashige, T. \& Skoog, F. A revised medium for rapid growth and bio assays with tobacco tissue cultures. Physiol. Plant. 15, 473-497 (1962).

32 Ma, Y., Prasad, M., Rajkumar, M. \& Freitas, H. Plant growth promoting rhizobacteria and endophytes accelerate phytoremediation of metalliferous soils. Biotechnol. Adv. 29, 248-258 (2011).

33 Liu, H. et al. Inner plant values: diversity, colonization and benefits from endophytic bacteria. Frontiers in Microbiology 8, 2552 (2017).

34 Bouizgarne, B. in Bacteria in agrobiology: disease management 15-47 (Springer, 2013).

35 Zinniel, D. K. et al. Isolation and characterization of endophytic colonizing bacteria from agronomic crops and prairie plants. Appl. Environ. Microbiol. 68, 2198-2208 (2002).

36 Hyder, S. et al. Characterization of native plant growth promoting rhizobacteria and their anti-oomycete potential against Phytophthora capsici affecting chilli pepper (Capsicum annum L.). Sci. Rep. 10, 1-15 (2020).

37 Swain, M. \& Ray, R. Biocontrol and other beneficial activities of Bacillus subtilis isolated from cowdung microflora. Microbiol. Res. 164, 121-130 (2009).

38 Etesami, H. \& Alikhani, H. A. Evaluation of gram-positive rhizosphere and endophytic bacteria for biological control of fungal rice (Oryzia sativa L.) pathogens. Eur. J. Plant Pathol. 147, 7-14 (2017).

39 Zhalnina, K. et al. Dynamic root exudate chemistry and microbial substrate preferences drive patterns in rhizosphere microbial community assembly. Nature Microbiology 3, 470-480 (2018).

40 Dinesh, R. et al. Isolation, characterization, and evaluation of multi-trait plant growth promoting rhizobacteria for their growth promoting and disease suppressing effects on ginger. Microbiol. Res. 173, 34-43 (2015).

41 Özyilmaz, Ü. \& Benlioglu, K. Enhanced biological control of phytophthora blight of pepper by biosurfactant-producing Pseudomonas. The plant Pathology Journal 29, 418 (2013).

42 Kim, S. G., Jang, Y., Kim, H. Y., Koh, Y. J. \& Kim, Y. H. Comparison of microbial fungicides in antagonistic activities related to the biological control of phytophthora blight in chili pepper caused by Phytophthora capsici. Plant Pathol J 26, 340-345 (2010).

43 Yang, M.-M. et al. Screening potential bacterial biocontrol agents towards Phytophthora capsici in pepper. Eur. J. Plant Pathol. 134, 811-820 (2012).

44 Syed-Ab-Rahman, S. F. et al. Identification of soil bacterial isolates suppressing different Phytophthora spp. and promoting plant growth. Frontiers in Plant Science 9, 1502 (2018).

45 Adibi, A., Rees, E. R., McCarley, S., Sica, V. P. \& Oberlies, N. H. Characterization and isolation of peptide metabolites of an antifungal bacterial isolate identified as Bacillus amyloliquefaciens subspecies plantarum strain FZB42. Journal of Microbiology, Biotechnology and Food Sciences $9,1309-1313$ (2020). 
47 Vessey, J. Plant growth promoting rhizobacteria as biofertilizer. Plant Soil 255, 571-586, doi:10.1023/A:1026037216893 (2003).

48 Syed-Ab-Rahman, S. F. et al. Soil bacterial diffusible and volatile organic compounds inhibit Phytophthora capsici and promote plant growth. Sci. Total Environ. 692, 267-280 (2019).

49 Pain, R., Duggan, P. \& Adams, D. in 10th international symposium on phototrophic prokaryotes, Barcelona, Spain. 147.

50 Qin, H. \& Huang, R. Auxin controlled by ethylene steers root development. International Journal of Molecular Sciences 19, 3656 (2018).

51 Mohite, B. Isolation and characterization of indole acetic acid (IAA) producing bacteria from rhizospheric soil and its effect on plant growth. Journal of Soil Science and Plant Nutrition 13, 638-649 (2013).

52 ALKahtani, M. D. et al. Isolation and characterization of plant growth promoting endophytic bacteria from desert plants and their application as bioinoculants for sustainable agriculture. Agronomy 10, 1325 (2020).

53 Khamna, S., Yokota, A., Peberdy, J. F. \& Lumyong, S. Indole-3-acetic acid production by Streptomyces sp. isolated from some Thai medicinal plant rhizosphere soils. EurAsian Journal of BioSciences 4, 23-32 (2010).

54 Datta, C. \& Basu, P. Indole acetic acid production by a Rhizobium species from root nodules of a leguminous shrub, Cajanus cajan. Microbiol. Res. $155,123-127$ (2000).

55 Wahyudi, A. T., Astuti, R. P., Widyawati, A., Mery, A. \& Nawangsih, A. A. Characterization of Bacillus sp. strains isolated from rhizosphere of soybean plants for their use as potential plant growth for promoting rhizobacteria. Journal of Microbiology and Antimicrobials 3, 34-40 (2011).

56 Apine, O. \& Jadhav, J. Optimization of medium for indole-3-acetic acid production using Pantoea agglomerans strain PVM. J. Appl. Microbiol. 110, 1235-1244 (2011).

57 Goswami, D., Dhandhukia, P., Patel, P. \& Thakker, J. N. Screening of PGPR from saline desert of Kutch: growth promotion in Arachis hypogea by Bacillus licheniformis A2. Microbiol. Res. 169, 66-75 (2014).

58 Abd El-Azeem, S., Mehana, T. \& Shabayek, A. in African Crop Sci. Conf. Proceed. 1517-1525.

59 Elias, F., Woyessa, D. \& Muleta, D. Phosphate solubilization potential of rhizosphere fungi isolated from plants in Jimma Zone, Southwest Ethiopia. International Journal of Microbiology 2016, 11 (2016).

60 Aliyat, F. Z., Maldani, M., El Guilli, M., Nassiri, L. \& Ibijbijen, J. Isolation and Characterization of Phosphate Solubilizing Bacteria from Phosphate Solid Sludge of the Moroccan Phosphate Minessolati. The Open Agriculture Journal 14, 16-24 (2020).

61 Batool, S. \& Iqbal, A. Phosphate solubilizing rhizobacteria as alternative of chemical fertilizer for growth and yield of Triticum aestivum (Var. Galaxy 2013). Saudi J. Biol. Sci. 26, 1400-1410 (2019).

62 Marschner, P., Crowley, D. \& Rengel, Z. Rhizosphere interactions between microorganisms and plants govern iron and phosphorus acquisition along the root axis-model and research methods. Soil Biol. Biochem. 43, 883-894 (2011).

63 Susilowati, L., Kusumo, B. \& Arifin, Z. in Journal Of Physics: Conference Series. 055082 (IOP Publishing).

64 Flemming, H.-C. \& Wingender, J. The biofilm matrix. Nature reviews microbiology 8, 623-633 (2010).

65 Backer, R. et al. Plant growth-promoting rhizobacteria: context, mechanisms of action, and roadmap to commercialization of biostimulants for sustainable agriculture. Frontiers in plant science 9, 1473 (2018).

66 Haque, M. M. et al. Biofilm Producing Rhizobacteria With Multiple Plant Growth-Promoting Traits Promote Growth of Tomato Under Water-Deficit Stress. Frontiers in Microbiology 11 (2020).

67 Marques, A. P., Pires, C., Moreira, H., Rangel, A. O. \& Castro, P. M. Assessment of the plant growth promotion abilities of six bacterial isolates using Zea mays as indicator plant. Soil Biol. Biochem. 42, 1229-1235 (2010).

68 Mukherjee, A., Singh, B. \& Verma, J. P. Harnessing chickpea (Cicer arietinum L.) seed endophytes for enhancing plant growth attributes and biocontrolling against Fusarium sp. Microbiol. Res. 237, 126469 (2020).

69 Sagar, A. Comparative Analysis of Production of Hydrogen Cyanide (HCN) with Production of Siderophore (SD) and Phosphate Solubilization (PS) Activity in Plant Growth Promoting Bacteria (PGPB). Vegetos 31, 130-135 (2018). 

463-471 (2008).

\section{Figures}
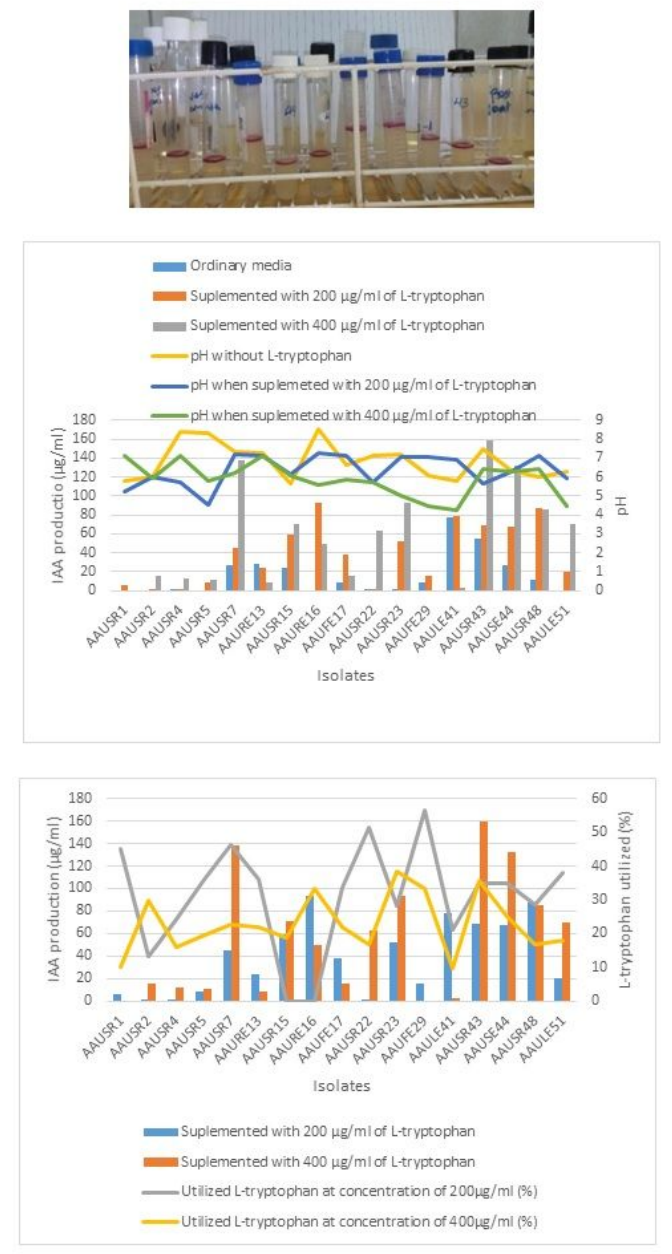

\section{Figure 1}

(a) Qualitative estimation of IAA production. (b) Quantitative estimation of IAA production by PGPB in the ordinary medium (NA), medium supplemented with 200 and, $400 \mu \mathrm{g} / \mathrm{ml}$ of L-tryptophan. (c) Effect of L-tryptophan on IAA Production, and L-tryptophan used by IAA producing bacteria 

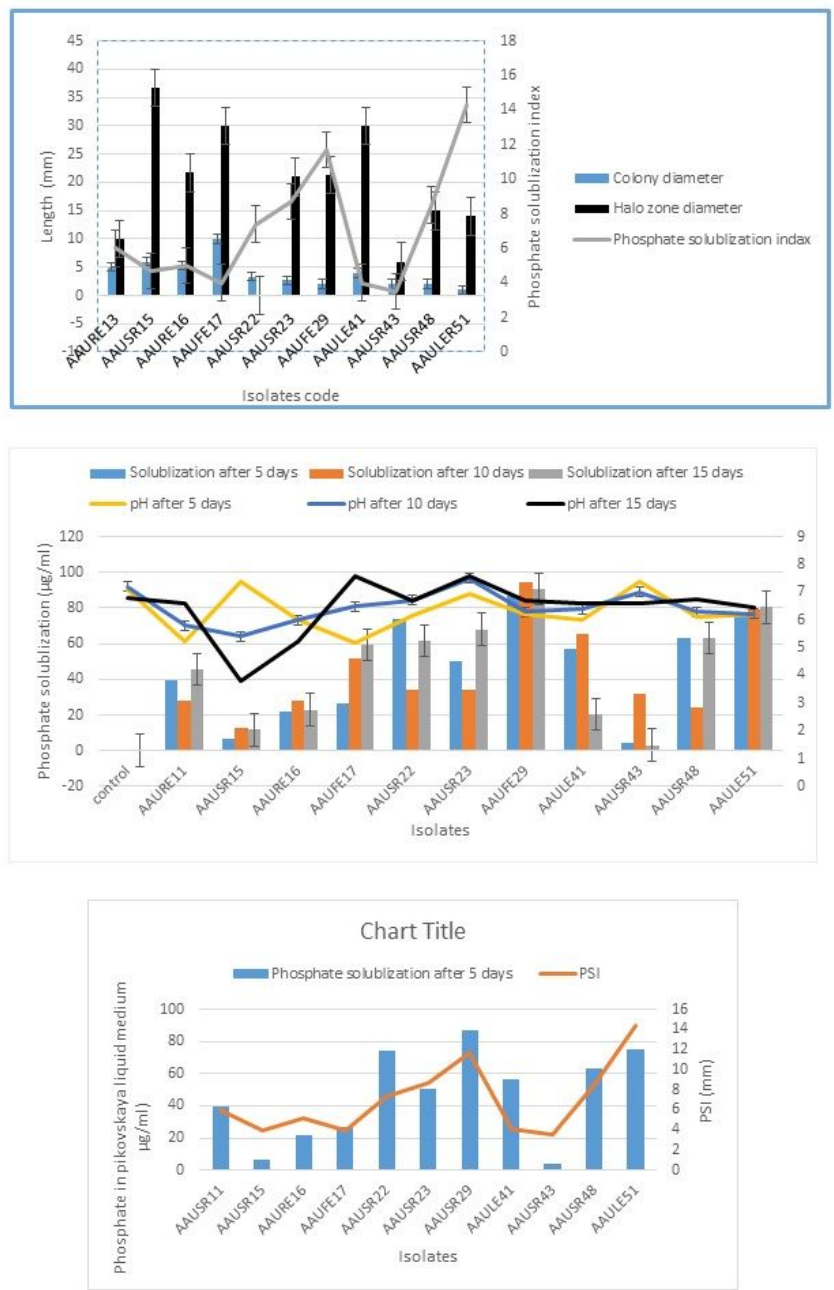

\section{Figure 2}

a Qualitative estimation of phosphate solubilizes on Pikovskaya's agar plate. b Quantitative estimation of phosphate solubilization of selected phosphate solubilizers in liquid pikovskaya's medium after 5, 10 and 15 days of incubation. c Correlation between PSI and phosphate solubilizing bacteria in liquid media 

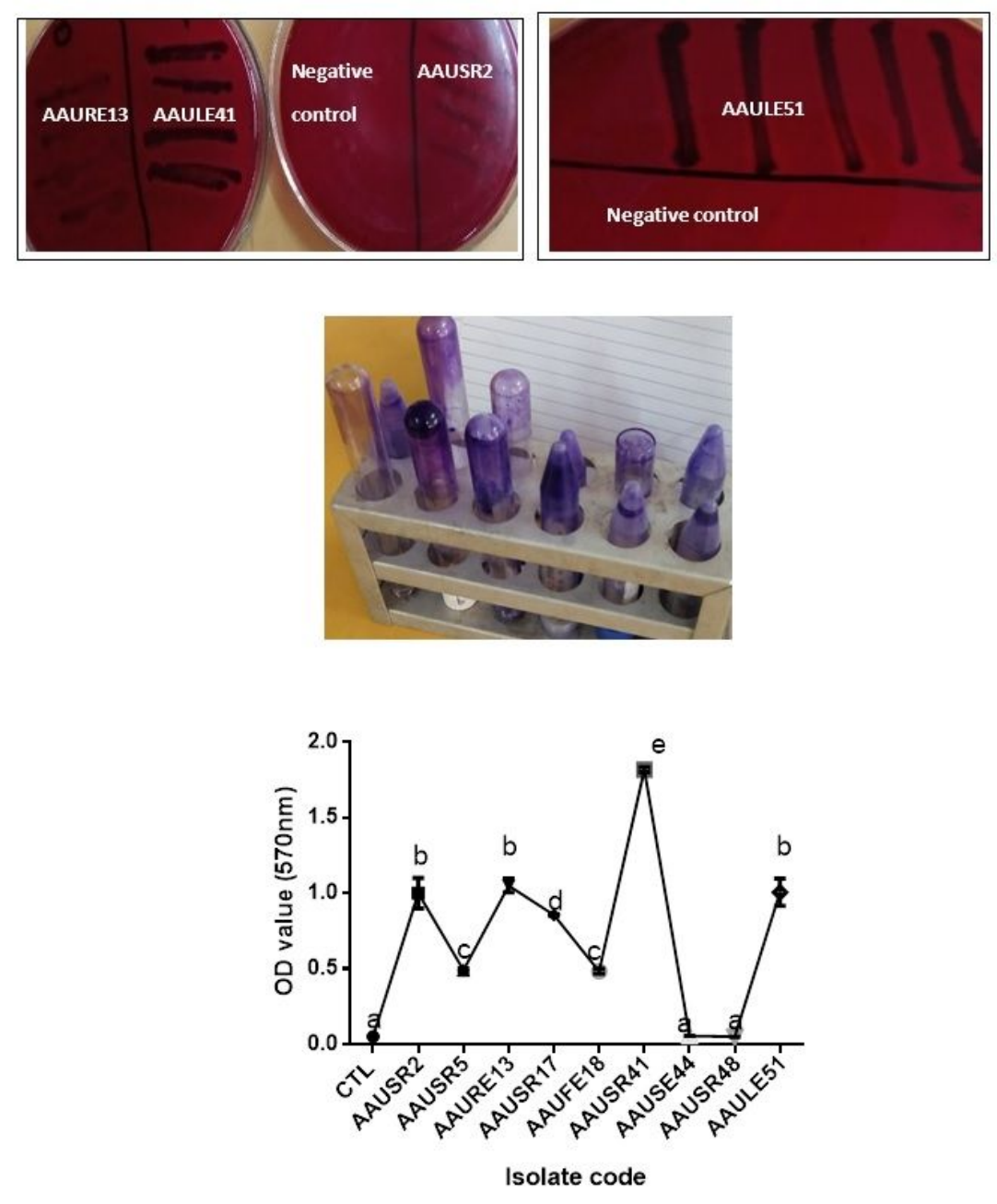

Figure 3

a Biofilm formation using plate methods. b Biofilm formation using tube methods. c Quantitative estimation of biofilm formation. Different letters above bars indicate a statistically significant difference $(P<0.05)$

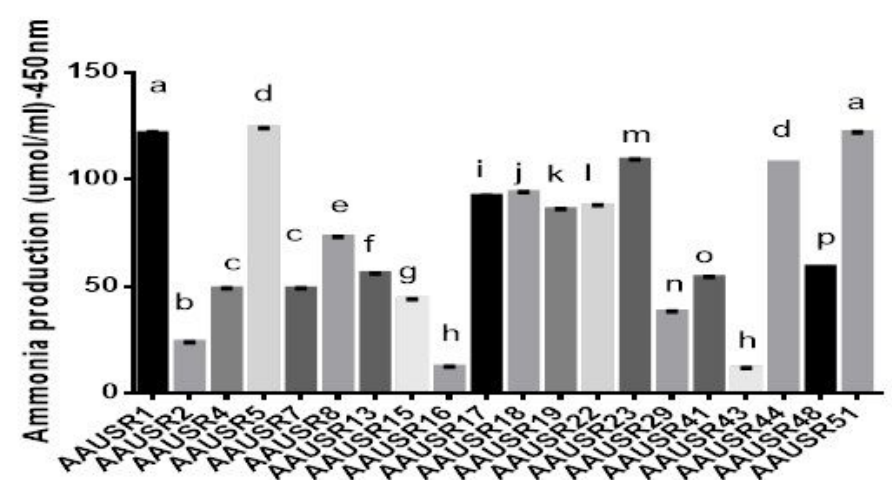

Isolate code

\section{Figure 4}

Qualitative estimation of ammonia production by selected bacterial isolates in peptone water using Nesslerization reaction. Different letters above bars indicate a statistically significant difference $(\mathrm{P}<0.05)$. 


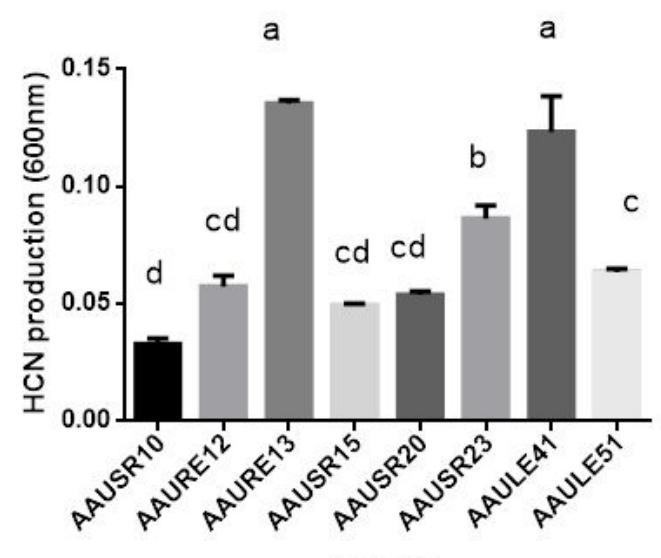

Isolates

\section{Figure 5}

Quantitative assay of $\mathrm{HCN}$ produced by bacterial isolates at $600 \mathrm{~nm}$ wavelength. Different letters above bars indicate a statistically significant difference $(\mathrm{P}<$ $0.05)$

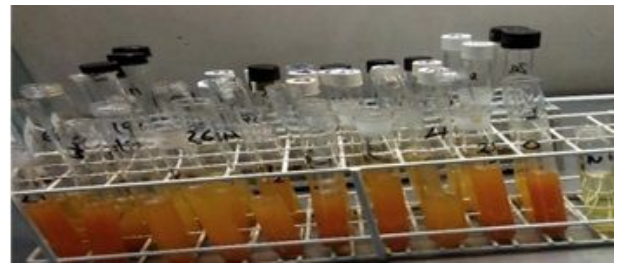

\section{Figure 6}

Qualitative estimation of ammonia production

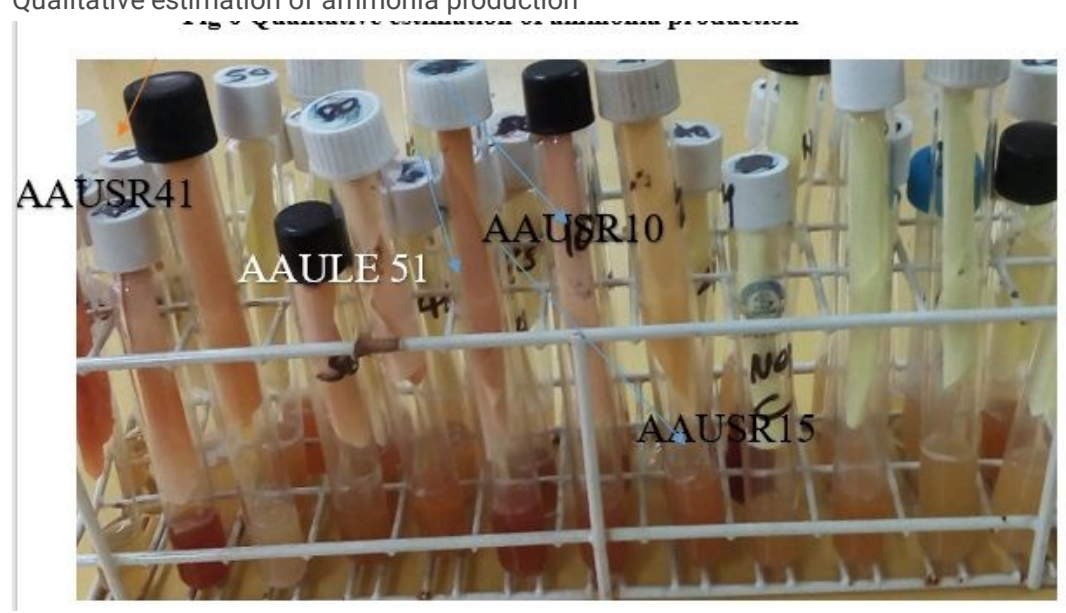

Figure 7

Qualitative estimation of HCN production 
A
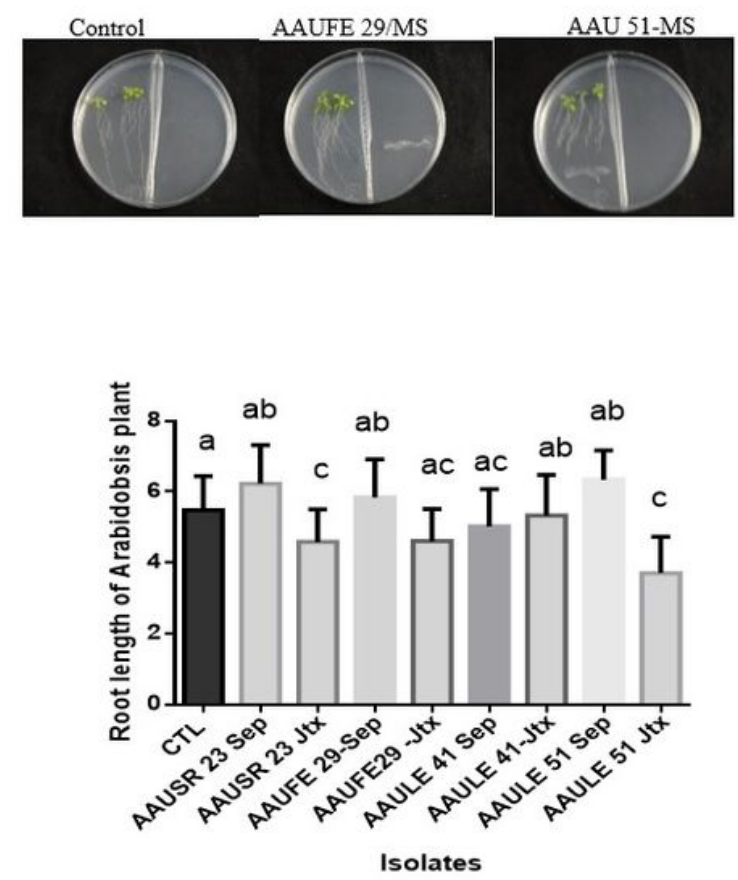

蒙
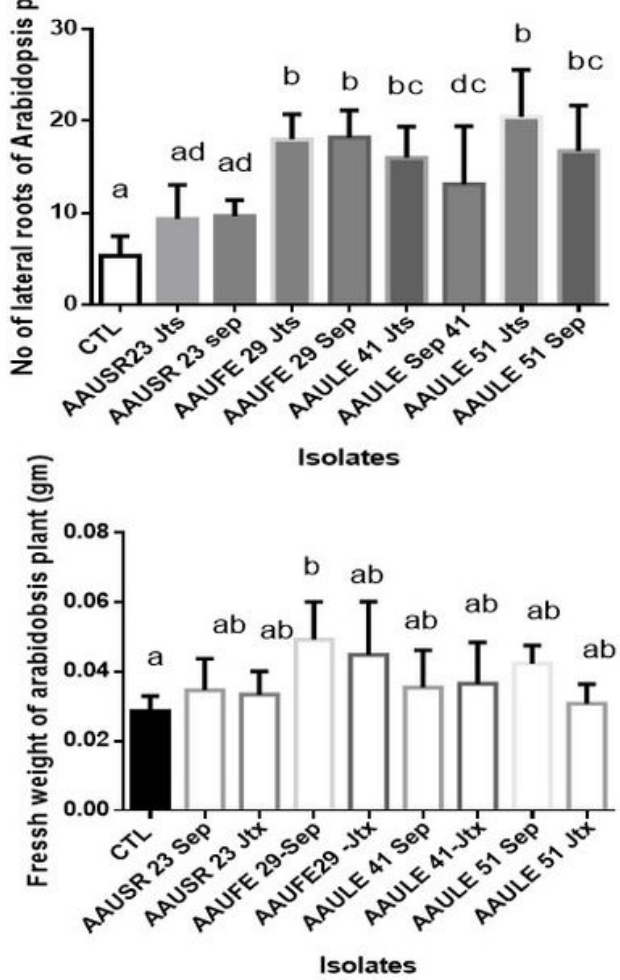

Figure 8

Effect of plant growth promoting bacteria on Arabidopsis plant at two days post inoculation (2 dpi). (A) 13 day-old Arabidopsis (Col-0) plants grown on MS media after 2 dpi with 4 selected bacterial strains were inoculated as follows: direct interaction of bacteria and Arabidopsis plant (AB-MS), split interaction of Arabidosis plant with bacteria grown on MS medium (AB/MS), and as control Arabidopsis plant grown on MS without any bacterial inoculation. (B) Primary root length $(n=15),(C)$ number of lateral roots of Arabidopsis plant per plant $(n=15)$, and (D) Fresh weight (mg) of Arabidopsis plant $(n=15)$. The bar plot represents mean $\pm S D$. Different letters above bars indicate a statistically significant difference $(P<0.05)$ 


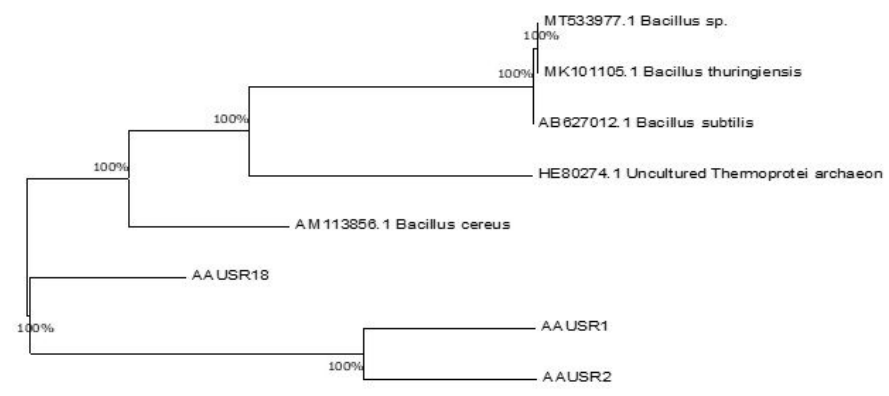

0.20

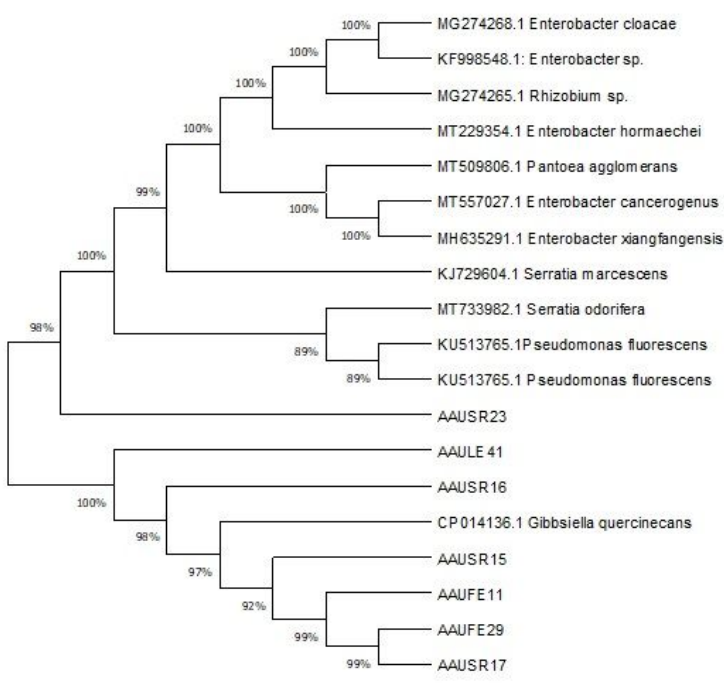

\section{Figure 9}

Phylogenetic relationship of gram positive (Fig.A), and gram negative (Fig.B) rhizosphere and endophytes of bacterial strain from pepper plants with plant growth promoting activities and antagonistic potential against $P$. capsici compared with bacterial strains showing sequence similarity. 